The Research Journal of the Costume Culture

[Original Article]

Received March 15, 2017

Revised April 21, 2017

Accepted May 12, 2017

${ }^{\dagger}$ Corresponding author

(nefa12@hanmail.net)

ORCID

Hyojung Suk

http://orcid.org/0000-0002-7065-3643

Lee eunjin

http://orcid.org/0000-0001-5745-2049

This work was supported by the National Research

Foundation of Korea Grant

funded by the Korean

Government

(NRF-2014S1A5B5A07041840).
pISSN 1226-0401

RJCC Vol.25, No.3, pp.253-269, June 2017

https://doi.org/10.7741/rjcc. 2017.25.3.253

\section{Fashion consumer's environmental awareness, pursuing values in disposal, sustainable fashion consumption attitude and fashion disposal behavior}

\author{
Hyojung Suk and Eun-Jin Lee ${ }^{\dagger}$ \\ Dept. of Fashion Design, Chung Ang University, Korea

\section{패션 소비자의 환경의식, 처분 추구가치, 지속가능한 패션소비태도와 패션처분행동에 관한 연구}

\author{
석 효 정·이 은 진 ${ }^{\dagger}$ \\ 중앙대학교 패션디자인전공
}

\begin{abstract}
This study identified fashion consumers disposal behavior and analyzed the effects of consumers pursuing values in disposal, environmental awareness, and sustainable fashion consumption attitudes in regards to fashion disposal behavior. A survey questionnaire was developed and data were obtained from 460 consumers in their 20's to 50's in Korea who had experienced fashion disposal behaviors during last 12 months. As a result, there were four different fashion disposal behaviors such as economical, practical, and social disposal as well as hoarding behaviors. Consumers pursuing values in disposal affected fashion disposal behavior. Practical and economical values had positively impacted economical disposal and hoarding behaviors. While hedonic value had a negative impact on economical disposal behavior, it had a positive impact on social disposal behavior. Also, environmental-social values had positively impacted practical and social disposal behaviors. Fashion-related environmental knowledge had positively impacted economical and practical disposal behaviors and PCE affected social disposal behavior, while environmental concerns had a negative impact on economical disposal behavior. Consumers attitude toward usedfashion items, fashion recycling, and fashion innovativeness affected all of fashion disposal behaviors. Although hoarding behavior has been an under researched area, the finding implied that hoarding behavior was affected by consumer's pursuing value in disposal and sustainable consumption attitude. Also, environmental-social values and attitudes toward used-fashion items would induce practical disposal behavior such as reuse by alteration or reform. Consumers economical and hedonic values can promote donations or exchange/resale of unwanted fashion items, which can lead to sustainable consumption.
\end{abstract}

Keywords: fashion disposal behavior(패션처분행동), environmental awareness(환경 의식), pursuing values in disposal(처분 추구가치), sustainable fashion consumption attitude(지속가능한 패션소비태도) 


\section{Introduction}

전 세계적으로 급증하는 패션 제품 폐기물은 환경 오염을 일으키는 주요 원인의 하나로 지목되고 있다. 글로벌 의류 생산은 2000년 이후 2배로 증가하였고, 글로벌 의류 매출액 또한 2015년 기준 1.8 조 달러 규 모로 급증하였으며, 소비자들은 그 어느 때보다 더 많 은 양의 의류를 구매하지만 예전에 비해 더 짧게 소비 하고, 더 많이 버리고 있다(“The environmental costs", 2017). 패션 제품의 처분행동은 구매나 사용 못지않 게 중요한 소비행동으로서, 더 이상 사용하지 않는 패션 제품을 어떻게 처분할 것인가는 소비자가 주도 적으로 결정하고 실행하는 소비자 행동의 마지막 단계 이며(Harrell \& McConocha, 1992), 지속가능한 패션 소비의 관점에서 소비자의 처분행동이 구매나 사용 행동보다 높게 나타나고 있다(Choi \& Kim, 2007).

그동안 패션산업은 지속가능한 발전을 위해 생산 과정에서의 환경적인 영향, 즉 지속가능한 재료의 사 용이나 유해 화학물질의 금지, 노동 및 인권문제 등 업스트림 생산망 관리에 중점을 두었으나, 최근에는 소비자의 사용이나 재사용, 사용 후의 관리 등 다운 스트림 생산망을 어떻게 관리해야 하는가에 관심을 두기 시작했다. 극히 일부 패션 브랜드들이 통합적 관점에서 제품의 라이프사이클 전 과정을 책임질 수 있는 비즈니스 모델에 대해 고민하고 있는데(Hvass, 2014 ) 아디다스, 파타고니아 등은 자원의 재활용을, $\mathrm{H} \& \mathrm{M}$ 과 유니클로, 막스앤스펜서는 제품의 수거와 재 활용 프로그램 활용을 실천하는 등 기업 차원에서 패 션 폐기물의 효율적인 선순환을 위해 노력하고 있다. 또한 소비를 통해 직간접적으로 나타나는 부정적인 사회적, 환경적 영향에 대한 '죄책감으로부터 자유로 운 소비', 최소의 것만을 소유하고자 하는 '미니멀 라 이프, 등이 새로운 소비 트렌드로 등장하면서, 이제 는 어떻게 하면 사회적, 환경적 영향을 고려하여 잘 버릴 수 있을 것인가에 관한 소비자의 관심이 증가하 고 있다.

소비자의 패션처분행동은 더 이상 사용하지 않는 패션 제품을 주변 사람에게 증여하거나 자선단체 기 부, 의류수거함 이용, 중고 교환 판매 또는 단순 폐기 행동 등 다양한 방식으로 나타난다. 하지만, 아까워서 혹은 미래에 입게 될지도 모른다는 생각에 처분하지 않고 수동적으로 보관하는 경우도 많으며, 대부분의
소비자는 자신이 보유하고 있는 패션 제품의 20 30\% 만을 실제로 착용하고, 나머지는 그대로 보관하거나 처분한다(Joung, 2014). 패션처분행동에 관한 기존의 연구에서는 처분의 유형을 분류하거나 원인을 파악 하고(Kang, 2013; Kim \& Cho, 2000), 처분행동에 영 향을 미치는 요인으로 환경의식이나 지식, 관심(Han, 2009; Park \& Oh, 2005; Suk \& Lee, 2013) 혹은 의류 재활용 태도(Jang \& Park, 1997; Roh \& Kim, 2002), 재활용 행동(Bianchi \& Birtwistle, 2012; Morgan \& Birtwistle, 2009) 등을 다루었으며, 유행에 대한 태도 나 유행추구가치가 처분행동에 영향을 주는 것으로 밝혀져 왔다(Ahn \& Ryou, 2015; Jang \& Park, 1997). 이와 같이 소비자의 환경의식과 유행추구가치, 재활 용 태도 및 행동 등이 패션처분행동에 영향을 주는 것으로 분석되었으나, 패션 제품을 처분하는데 있어 소비자들이 추구하는 가치와 지속가능한 패션소비태 도의 영향력은 직접적으로 확인되지 않았으므로 이 를 고려한 연구가 필요하다.

소비자가 패션 제품을 어떻게 처분할 것인가를 결정 하는데 있어 영향을 미칠 수 있는 심리적 변인으로 처 분을 통해 추구하는 가치나 동기를 밝히려는 시도가 여러 질적 연구(Albinsson \& Perera, 2009; Birtwistle \& Moore, 2007; Ha-Brookshire \& Hodges, 2009; Lee, Halter, Johnson, \& Ju, 2013)를 통해 이뤼졌는데, 소 비자는 패션 제품을 처분할 때 정리 정돈의 만족감을 얻거나, 새로운 공간을 확보하려는 실용적 가치를 추 구하기도 하고, 자선적 의미나 자원의 보존 등의 사회 환경적 가치 혹은 재판매를 통한 경제적 이득을 추구 하는 것으로 나타났다. 즉, 소비자들은 패션 제품을 처분할 때 다양한 가치를 추구하며, 이러한 추구가치 에 따라서 소비자의 패션처분행동이 달라질 것으로 유추할 수 있다. 또한 다수의 국내 연구(Kwon, Kim, \& Lee, 2002; Park \& Oh, 2005)에서는 처분행동에 수동적 보관이나 단순 폐기행동은 제외하고, 기부나 중고판매, 증여 등에 중점을 두고 연구를 진행하였으 나, 패션 제품의 단순보관이나 폐기율이 높은 점(Kang, 2013)을 고려한다면 소극적 처분을 포함하여 처분행 동에 관한 연구의 범위를 확장시킬 필요가 있다.

따라서 본 연구에서는 적극적 처분과 소극적 처분 을 포함하여 소비자의 패션처분행동의 유형을 알아 보고, 패션 제품 처분을 통한 추구가치와 환경의식, 지속가능한 패션소비태도 등의 심리적 변인이 처분 
행동에 미치는 영향을 분석함으로써 소비자의 지속 가능한 소비행동을 이해하는데 유용한 학문적 자료 를 제공하고자 한다. 본 연구의 결과는 패션처분행동 을 파악하고, 처분행동에 영향을 미치는 요인이 무엇 인지를 밝힘으로써 패션 소비자의 지속가능한 소비 및 처분행동을 유도하는 방안을 제시하고 패션 기업 이 자원의 선순환과 제품의 지속가능성 전략을 수립 하는데 도움이 될 수 있다.

\section{Background}

\section{Fashion disposal behavior}

패션처분행동이란 소비자가 패션 제품을 구매, 사 용 후에 더 이상 착용하지 않는 제품을 처분하는 행 동을 말한다. 패션처분행동의 개념은 패션 제품의 소 비과정 모델을 토대로 능동적 사용, 수동적 보관, 폐 기라는 세 가지 과정이 동시에 일어나는 수정된 소비 과정 모델(bathtub model)로 발전하였는데(Veverka, 1974 as cited in Kwon, Kim, \& Lee, 2002), 처분 유 형에 따라 경제적 처분, 책임있는 처분, 무책임한 처 분행동(Harrell \& McConocha, 1992; Jang \& Park, 1997)으로 분류할 수 있다. 경제적 처분은 중고판매 및 교환, 헌옷을 수거하고, 무게에 따라 현금을 지불 하는 수거업체 이용 등 경제적 이득을 취하는 행동이 며, 책임있는 처분은 자선단체나 기관에 기부하거나 의류수거함을 이용하는 행동, 가족이나 친척, 친구에 게 증여하는 행동을 말한다. 또한 더 이상 입지 않지 만 영구 처분하지 않고 그대로 보관하는 수동적 보관 이나 일반 쓰레기로 취급해서 단순 폐기하는 경우는 무책임한 처분행동으로 분류할 수 있다. 기존의 국내 연구에서는 재활용 행동을 처분행동과 같은 의미로 사용하여 제품의 판매, 기증, 교환행동(Roh \& Kim, 2002), 혹은 재판매 및 교환, 타 용도로 변경, 증여 및 기증행동(Kwon et al., 2002; Park \& Oh, 2005)에 초 점을 두고 연구하였다. Jang and Park(1997)은 처분행 동이라는 용어를 사용했지만, 보관과 폐기는 연구대 상에서 제외하고 경제적 처분(중고판매, 물물교환, 다 른 용도로 개조)과 이타적 처분(증여나 기부)만 포함 시켰다. 그러나 성인여성의 경우, 전체 의복량의 약 $25 \%$, 새 옷의 약 $30 \%$ 를 활용하지 않고 그대로 보관 하고 있으며(Kang, 2013), 입지 않는 옷을 교환하거
나 재판매, 수선이나 기증하기보다는 그대로 옷장에 보관하거나 폐기하는 경우가 많다(Han, 2009; Huh, 2007). 따라서 소비자의 패션처분행동을 좀 더 깊게 이해하기 위해서는 보관이나 단순폐기 행동 또한 처 분행동에 포함되어야 하며, '재활용 행동'보다는 '처 분행동'이라는 용어가 적합하다고 판단된다.

패션처분행동에 영향을 미치는 관련변인으로는 환 경의식적 혹은 사회적 책임 소비행동이 주로 다뤄지 고 있는데, 일반적인 재활용 행동, 환경의식 등이 재활 용 태도나 행동에 미치는 영향(Bianchi \& Birtwistle, 2010, 2012; Morgan \& Birtwistle, 2009; Park \& Oh, 2005; Roh \& Kim, 2002)을 밝히고자 하였다. 또한 패션라이프스타일에 따른 의복의 사장 및 재활용행 동(Kwon et al., 2002), 성인여성의 착용하지 않는 의 복현황과 의류폐기 원인(Kang, 2013; Kim \& Cho, 2000), 사회적 책임 의류 소비태도(Jang \& Park, 1997; Park, Park, \& Lee, 2014), 의복소비가치(Ahn \& Ryou, 2015; Lang, Armstrong, \& Brannon, 2013) 등 소비자 의 의류처분유형이나 원인을 밝히고자 하는 연구가 이뤼졌다. 최근에는 포커스 그룹이나 심층 인터뷰를 이용한 질적 연구(Albinsson \& Perera, 2009; Birtwistle \& Moore, 2007; Ha-Brookshire \& Hodges, 2009; Lee et al., 2013; Morgan \& Birtwistle, 2009)를 통해 패션 제품의 처분 동기나, 처분을 통해 경험하는 가치, 감 정의 차원 등을 밝혀내려는 시도가 이뤄졌는데, 처분 을 통해 긍정과 부정의 감정을 경험하고, 처분 동기 에 따라 처분행동을 결정하기도 하며, 처분행동을 통 해 추구하는 가치가 다르게 나타나기도 한다.

따라서 본 연구에서는 처분행동을 통해 추구하는 가치요인을 분류하고 처분추구가치와 환경의식, 지속 가능한 소비태도가 처분행동에 미치는 영향을 알아 보고자 한다. 또한 패션처분행동을 적극적 처분과 소 극적 처분으로 나누고, 적극적 처분은 중고판매 및 교환을 통한 경제적 처분, 기부 및 증여하는 사회적 처분, 리폼 및 수선을 통해 재활용하는 실용적 처분 으로 분류하고, 소극적 처분은 단순 폐기와 수동적 보관을 포함하고자 한다.

2. Pursuing value in disposal, environmental awareness, and sustainable fashion consumption attitude 


\section{1) Pursuing value in disposal}

처분 추구가치는 소비자가 패션 제품의 처분을 통 해 얻고자 하는 가치를 의미한다. 개인의 가치는 행 동과 의사결정을 이끌고 동기를 유발하는 근본적인 신념으로 소비행동에 중요한 역할을 하는데(Lee et al., 2013), 소비자는 패션처분행동을 전후로 긍정과 부정의 감정을 경험하기도 하고, 처분행동을 통해 실 용적, 쾌락적, 사회적 책임 가치를 경험하기도 한다. 대부분의 개인은 자신이 가져다 놓은 헌 옷이 직간접 적으로 누군가를 돕는 수단으로 활용된다는데 자부 심을 갖고 있으며 나눔을 실천했다는 점에서 사회적 선행의 한 방식으로 해석하고, 의류 재활용의 중요한 목적이 사회적 선행과 실천에 있다고 인식한다(Cho, 2010).

소비자는 처분행동을 통해 새 옷을 위한 공간마련, 정리 정돈을 통한 만족감, 타인을 돕는다는 기쁨, 중 고판매를 통한 경제적 이득 등 다양한 가치를 추구한 다(Albinsson \& Perera, 2009; Ha-Brookshire \& Hodges, 2009; Lee et al., 2013). Albinsson and Perera(2009) 는 의복교환행사에 참여한 소비자를 대상으로 한 심 층면접을 통해 이들이 자원 절약과 환경 보호의 사회 적 가치, 새로운 패션 아이템을 찾는 쾌락적 가치를 경험하고, 의복 교환을 통해 자신이 지속가능한 소비 에 도움을 주었다는 자부심을 느끼며 개인의 특성에 따라 처분행동의 유형이 달라질 수 있다고 하였다. Lee et al.(2013)은 유행성과 패션 제품의 물리적 상 태, 다른 사람을 돕고자 하는 사회적 책임감이 처분 행동을 유발한다고 하였으며, Joung and Park-Poaps (2013)는 처분동기를 환경적, 경제적, 자선적, 편의성, 정보이용성으로 분류하고, 환경적 동기가 재판매와 기부행동에, 경제적 동기가 재판매와 재사용에, 자선 적 동기가 기부행동에, 편의성이 단순폐기행동에 영 향을 미친다고 하였다. 또한 의복소비가치가 처분행 동에 미치는 영향을 연구한 Ahn and Ryou(2015)는 개성추구가치는 기부행동, 유행추구는 폐기와 양도, 실용적 가치추구는 양도와 기부행동에 정적 영향을 미 치고, 폐기행동에는 자기표현가치와 실용적 가치가 부적 영향을 미친다고 하였다.

이러한 선행 연구의 결과를 바탕으로 소비자의 처 분 추구가치에 따라 처분행동의 유형이 달라질 수 있 음을 유추할 수 있다. 몇몇 연구에서 패션 제품의 기
부행동을 남을 돕고자 하는 마음이나 자선에 관한 관 심 등 사회적 가치와 연관짓고 있지만(Birtwistle \& Moore, 2007; Ha-Brookshire \& Hodges, 2009; Joung \& Park-Poaps, 2013; Lee et al., 2013), 대부분 질적 연구를 통해 나타난 결과이므로 양적 연구를 통해 처 분행동과의 영향관계를 규명할 필요가 있다. 따라서 본 연구에서는 패션처분행동을 통해 경제적 이익을 추구하는 경제적 가치, 옷장정리의 목적 달성을 통한 개인적 즐거움이나 죄책감으로부터의 자유로움을 추 구하는 쾌락적 가치, 새 옷을 위한 공간 마련이나 공 간확보 등을 추구하는 실용적 가치, 나눔의 실천과 자원의 재활용으로 환경과 사회에 책임있는 행동을 하고자 하는 환경사회적 가치추구로 분류하여 추구 가치가 패션처분행동에 미치는 영향을 알아보고자 한다.

\section{2) Environmental awareness}

패션처분행동에 영향을 미치는 변인으로 환경에 대한 태도는 환경친화적 처분 행동과 유의한 관계가 있으며, 환경의식 정도에 따라 처분행동이 달라진다 (Bianchi \& Birtwistle, 2010; Han, 2009). 환경에 대한 관심은 소비자 효과성 지각(perceived consumer effectiveness)과 함께 환경의식을 구성하는 주요 변수이며 (Park et al., 2014), 환경에 관한 관심이나 지식은 환 경의식적 처분행동에 유의한 영향을 미친다(Choi \& Kim, 2007; Park \& Oh, 2005).

소비자 효과성 지각은 개인의 노력이 환경문제를 해결하는데 어느 정도의 효과를 발휘할 수 있다고 믿 는 것으로, 소비자 효과성 지각이 높은 소비자들은 보다 의식적인 소비행동을 한다(Suk, 2015). 소비자 효과성 지각과 패션처분행동 간의 영향관계에 대해 서는 밝혀진 바가 없으나, 소비자 효과성 지각이 환 경의식적 소비태도와 행동에 영향을 미치고, 소비자 효과성 지각이 높을수록 의류 재활용에 대해 더욱 긍 정적이며, 의류소비에 있어 자원 보존을 중요시 한다 는 연구결과(Park et al., 2014)를 고려해볼 때 소비자 효과성 지각이 소비자의 처분행동에도 영향을 미칠 것으로 유추할 수 있다.

환경지식은 환경문제와 관련해 개인이 갖고 있는 사실이나 개념 및 생각으로 윤리문제와 관련한 지식 과 지속가능 환경지식은 소비자의 지속가능한 관리 
및 처분행동에 유의한 영향을 미친다(Suk \& Lee, 2013). Kang(2013)의 연구에서는 패션산업의 환경오 염에 대한 인식수준이 높은 집단이 새 옷을 타인에게 주거나, 헌옷 수거함에 넣는 등 재활용비율이 높고, 그대로 보관하는 비율은 현저히 감소한다고 하였다. $\operatorname{Han}(2009)$ 의 연구에서는 의복관련 환경의식이 낮은 집단이 수선 및 재활용, 교환 및 재판매, 기증, 분리수 거 행동을 덜 하고 수동 보관하는 비율이 높은 것으 로 분석되었으나, 환경에 대한 지식이 많을수록 자선 단체에 기부하는 것보다는 친구나 가족에게 증여하 는 경향이 있는 것으로도 밝혀져 왔다(Bianchi \& Birtwistle, 2012). 또한 환경교육의 경험이 있는 경우에는 이타적 처분행동이 높게 나타났고, 교육경험이 없는 경우에는 의복을 폐기하는 비율이 높게 나타났다(Kim \& Cho, 2000).

환경에 관한 관심은 일반적으로 환경문제에 얼마 나 관심을 갖고 있는가로 나타나는데, 지속가능한 소 비행동에 영향을 미치는 주요 변인으로 알려져 있다. Joung and Park-Poaps(2013)는 환경관심은 재판매와 기부행동에 영향을 미치고, Morgan and Birtwistle (2009)에 의하면 의류를 너무 많이 보유하고 있다고 느낄 때 처분행동에 적극적이며, 환경에 대한 관심이 많고, 일반적인 재활용 행동을 많이 할수록 입지 않는 옷을 자선단체에 기부한다고 하였다. 본 연구에서는 환 경의식을 구성하는 변수로 소비자 효과성 지각(PCE), 환경에 관한 관심(concern), 패션산업과 관련한 환경 지식(knowledge)을 주요 변수로 포함하여 환경의식 이 패션처분행동에 미치는 영향을 알아보고자 한다.

\section{3) Sustainable fashion consumption attitude}

지속가능한 패션소비태도는 패션소비에 있어 구매, 사용 및 관리, 처분의 전 단계에 걸쳐 환경과 사회적 책임을 고려하는 소비태도를 의미한다. 기존 연구에 서 사회책임적 의류소비 태도 혹은 환경의식적 의류 소비태도 등 다양한 용어를 사용하고 있으나, 환경이 나 사회적 책임 모두 궁극적 목적은 지속가능성의 추 구임을 고려할 때 지속가능한 패션소비태도는 이들 개념을 모두 포함한다고 할 수 있다. 지속가능한 소 비태도의 하위차원으로는 패션 혁신성(Bianchi \& Birtwistle, 2010), 소비성향(Lang et al., 2013), 의복 재활 용에 대한 태도, 친환경적 의복구매행동, 슬로패션 구
매의사(Han, 2009) 등이 패션처분행동에 영향을 미치 는 것으로 나타났다. 또한 중고의류제품, 의류 재활용, 유행, 자원보존에 대한 태도에 따라 처분행동 유형이 다르게 나타난다(Jang \& Park, 1997; Park et al., 2014).

중고패션 제품에 대한 소비자 태도는 중고패션 제 품에 대한 소비자의 긍정적 혹은 부정적 평가로서 중 고패션 제품에 대한 지속적인 선호도라고 할 수 있다 (Choo \& Park, 2013). 재사용 재활용 패션이용 소비 자들은 대체로 개성이 강하고, 패션관여가 높으며, 패 션아이템으로써 가치가 있다고 판단될 때 구입을 결 정한다(Yoon, Jin, \& Kang, 2013). 중고 의류 구입에 호의적인 태도를 보일수록 경제적 처분을, 유행지향 적 의류 소비에 대해 부정적인 태도를 가지거나, 의 류 재활용이 바람직하다고 생각하는 실용적인 태도 를 가질수록 주위 사람들에게 의류를 주거나, 자선단 체에 기증하는 이타적 처분행동을 더 많이 한다(Jang $\&$ Park, 1997). 또한 업사이클링에 대해 알고 있는 중 고등학생이 환경의식, 의복재활용행동, 패션관심이 모두 높고, 업사이클링 제품구매경험자들이 환경의식 이 높고, 의복재활용행동에도 적극적이며, 패션에 대 한 관심도 높은 것으로 나타났다(Park \& Shin, 2014).

특히 패션 혁신성, 유행에 대한 태도는 패션처분행 동에 유의한 영향을 미치는데 (Bianchi \& Birwistle, 2010; Lee et al., 2013), 유행추종의 원인이 적을수록 남에게 주거나 기부하는 이타적 처분행동이 높게 나 타나며(Jang \& Park, 1997; Kim \& Cho, 2000), 패션 유행에 민감한 집단이 그렇지 않은 집단보다 패션 제 품을 더 자주 구매하며, 더 자주 처분한다(Lang et al., 2013). 그러나 패션 혁신성이나 유행에 대한 태도와 처분행동 간의 영향관계에서는 상반된 연구 결과가 나오기도 한다. Ahn and Ryou(2015)는 유행추구가치 가 헌 옷 수거함에 넣는 처분행동에는 정적 영향을 미쳤으나, 친구나 가족에게 양도하는 행위에는 부적 영향을 미쳤고, Bianchi and Birwistle(2010)은 패션혁 신성이 자선단체에 기부하는 행동에는 유의한 영향 을 미치지 않았으나, 친구나 가족에게 증여하는 행동 에는 유의한 영향을 미친다고 밝히고 있다. 본 연구 에서는 지속가능한 패션소비태도를 구성하는 요인으 로 중고패션 제품 태도, 패션재활용 태도, 패션혁신성 으로 분류하여 연구하고자 하며, 지속가능한 패션소 비태도가 처분행동에 미치는 영향을 알아보고자 한다. 


\section{Methods}

\section{Research proposal}

연구문제 1. 소비자의 패션처분행동, 처분 추구가 치, 환경의식 및 지속가능한 패션소비태도의

구성요인을 분석한다.

연구문제 2. 소비자의 패션 제품 처분 추구가치, 환경의식 및 지속가능한 패션소비태도가 패션 처분행동에 미치는 영향을 분석한다.

2-1. 소비자의 처분 추구가치가 패션처분행동 에 미치는 영향을 분석한다.

2-2. 소비자의 환경의식이 패션처분행동에 미 치는 영향을 분석한다.

2-3. 소비자의 지속가능한 패션소비태도가 패 션처분행동에 미치는 영향을 분석한다.

\section{Instrument development}

본 연구의 측정 도구로는 설문지를 사용하였고, 처 분 추구가치, 환경의식, 지속가능한 패션소비태도, 패 션처분행동과 인구통계적 특성에 관한 항목으로 구 성하였다. 소비자가 패션 제품을 처분하는 과정에서 얻고자 하는 처분 추구가치를 측정하기 위해 Ha-Brookshire and Hodges(2009), Lee et al.(2013) 등의 질적 연구와 Joung and Park-Poaps(2013)의 연구, 예비조 사 결과를 참고하여 항목을 개발하였다. 구체적으로, 실용적 가치는 Albinsson and Perera(2009), Ha-Brookshire and Hodges(2009)의 연구를 참고하여 새로 산 패션 제품을 보관할 공간이 필요하거나 정리 정돈을 위해 더 이상 입지 않는 옷이나 가방, 신발 등을 처분 한다는 항목으로 구성하였고, 쾌락적 가치는 Lee et al. (2013)의 연구를 토대로 정리 정돈을 통해 만족감을 느끼고, 기분이 좋아진다는 항목으로 구성하였다. 또 한 Joung and Park-Poaps(2013)와 Lee et al.(2013)의 연구를 참조하여 교환 판매 등을 통해 경제적 이득을 얻고자 하는 경제적 가치, 환경보호와 자원절약, 기부 를 통해 타인에게 도움을 주고자 하는 환경사회적 가 치를 포함하여 총 12 항목으로 구성하였고, 각 문항은 5점 리커트 척도로 측정하였다.

환경의식은 소비자 효과성 지각과 패션산업과 관 련한 환경지식 및 환경관심을 측정하기 위해 $\mathrm{Suk}$ (2015), Suk and Lee(2013)의 연구와 예비조사 결과 를 참고하여 14항목으로 구성하였고, 5점 리커트 척
도로 측정하였다. 지속가능한 패션소비태도는 패션혁 신성, 중고패션 제품 및 패션 제품 재활용에 대한 태 도를 측정하기 위해 Bianchi and Birtwistle(2010), Jang and Park(1997), Kang(2013), Roh and Kim(2002)의 연구와 예비조사 결과를 참고하여 15 항목으로 구성 하였고, 5점 리커트 척도로 측정하였다. 패션처분행 동은 Bianchi and Birtwistle(2010), Han(2009), Joung and Park-Poaps(2013), Kang(2013) 등의 연구와 예비 조사 결과를 참고하여 13항목으로 구성하였고, 5점 리커트 척도로 측정하였으며, 인구통계적 특성에 관 한 4 문항은 명목척도로 측정하였다.

\section{Sampling and data analysis}

본 연구는 자료 수집을 위하여 최근 1 년 동안 옷장 정리를 통해 패션 제품을 처분해 본 경험이 있는 국 내 거주 20 50대 남녀 소비자를 대상으로 설문조사 를 실시하였다. 설문조사는 예비조사와 본 조사의 두 가지 방법으로 진행하였고, 예비조사는 패션 제품의 처분경험이 있는 대학생 혹은 대학원생 100 명을 대상 으로 하였으며, 응답자들이 이해하기 힘들거나 적합 하지 않다고 지적한 항목은 수정 및 보완하였으며, 예 비조사 결과를 분석하여 측정항목의 신뢰성과 타당 성을 확보하였다.

본 조사는 편의표집방식으로 전문 설문조사기관을 통한 인터넷 설문지를 이용하여 2015년 7월 12일부터 일주일간 실시하였으며, 총 460 부를 자료 분석에 사용 하였다. 수집된 자료는 SPSS WIN을 이용하여 빈도 분석, 신뢰도 분석, 요인분석(주성분 분석, Varimax회 전, 고유치 1.0 이상 요인추출), 다중회귀분석(multiple regression analysis: enter method)을 실시하였다. 본 연구의 조사 대상은 남성 $49.3 \%$, 여성 $50.7 \%$ 이었고, 연령은 20 대 $24.1 \%, 30$ 대 $24.8 \%, 40$ 대 $25.2 \%, 50$ 대 $25.9 \%$ 로 고루 분포되어 있었다. 결혼 여부는 미혼 $41.5 \%$, 기혼 $58.5 \%$, 학력은 대학교 졸업 및 대학원 재학 이 상이 $72.4 \%$ 를 차지해 학력수준이 높은 편이었다.

\section{N. Results and Discussion}

1. The components of fashion disposal behavior, pursuing value in disposal, environmental awareness and sustainable fashion consumption attitude 


\section{1) Fashion disposal behavior}

소비자의 패션처분행동 문항을 요인분석한 결과, 〈Table 1)과 같이 고유치 1.0 이상인 4 요인이 도출되 었고, 요인분석 과정에서 요인부하량 .50 이하인 3 항 목이 제거되어 총 10 문항이 최종 분석에 사용되었으 며, 요인의 총 변량은 $73.34 \%$ 였다. 요인 1 은 더 이상 착용하지 않는 패션 제품을 직접 인터넷 중고시장 등 을 통해 중고로 판매하거나 중고 거래인에게 판매, 중고상점에서의 물물교환 등 경제적 이익을 취하는 경제적 처분행동, 요인 2 는 더 이상 착용하지 않는 패 션 제품이라도 나중을 위해 처분하지 않고, 옷장이나 신발장, 박스 등에 정리하여 보관하는 소극적 처분인 수동적 보관행동, 요인 3은 유행이 지난 패션 제품이 나 몸에 맞지 않는 옷이라도 수선하거나 리폼하여 다 시 활용하는 실용적 처분행동, 요인 4는 가까운 헌 옷 수거함이나 가족, 친척이나 이웃 등에게 증여하는 사 회적 처분행동으로 추출되었다. 다항목 척도 간의 신
뢰성을 크론바하 알파계수에 의해 분석한 결과, 모든 요인의 신뢰 계수가 .60 이상을 보여 문항의 신뢰성 이 검증되었다. 이러한 결과는 수동적 보관행동을 처 분행동의 범위에서 제외했던 기존의 연구(Ahn \& Ryou, 2015; Bianchi \& Birtwistle, 2010; Jang \& Park, 1997; Kim \& Cho, 2000)와 달리, 사용하지 않 는 패션 제품일지라도 수동적 보관을 택하는 경향이 높다는 여러 질적 연구(Ha-Brookshire \& Hodges, 2009; Joung, 2014; Lee et al., 2013)의 결과를 지지 한다. 따라서 소비자의 패션처분행동에는 증여나 기 부, 판매, 재활용뿐 아니라, 실제로 처분하지 않더라 도 그대로 보관하는 수동적 보관행동을 포함시켜야 할 것이다.

\section{2) Pursuing value in disposal}

소비자가 패션 제품을 처분하는 과정에서 얻고자하 는 추구가치의 유형을 요인분석 한 결과, 〈Table 2〉와

$<$ Table 1> Factor analysis result of fashion disposal behavior

\begin{tabular}{|c|c|c|c|c|c|}
\hline Factors & Items & $\begin{array}{l}\text { Factor } \\
\text { loading }\end{array}$ & $\begin{array}{l}\text { Eigen } \\
\text { value }\end{array}$ & $\begin{array}{c}\text { Cumulative } \\
(\%)\end{array}$ & $\begin{array}{c}\text { Cronbach's } \\
\quad \alpha\end{array}$ \\
\hline \multirow{3}{*}{$\begin{array}{c}\text { Economical } \\
\text { disposal } \\
\text { behavior }\end{array}$} & $\begin{array}{l}\text { I sell fashion products that I wouldn't wear any longer to } \\
\text { online market such as ebay. }\end{array}$ & .829 & \multirow{3}{*}{2.348} & \multirow{3}{*}{23.479} & \multirow{3}{*}{.788} \\
\hline & $\begin{array}{l}\text { I sell fashion products that I wouldn't wear any longer to } \\
\text { second-hand agents. }\end{array}$ & .821 & & & \\
\hline & $\begin{array}{l}\text { I exchange fashion products that I wouldn't wear any } \\
\text { longer at second-hand stores such as kiple. }\end{array}$ & .760 & & & \\
\hline \multirow{3}{*}{$\begin{array}{l}\text { Hoarding } \\
\text { behavior }\end{array}$} & $\begin{array}{l}\text { I keep fashion products in drawers or closets even though } \\
\text { I wouldn't wear any longer. }\end{array}$ & .896 & \multirow{3}{*}{2.189} & \multirow{3}{*}{45.373} & \multirow{3}{*}{.796} \\
\hline & $\begin{array}{l}\text { I will not dispose fashion products for future use even } \\
\text { though I wouldn't wear any longer. }\end{array}$ & .883 & & & \\
\hline & $\begin{array}{l}\text { I organize fashion products that I wouldn't wear any } \\
\text { longer and store in boxes. }\end{array}$ & .687 & & & \\
\hline \multirow{2}{*}{$\begin{array}{l}\text { Practical } \\
\text { disposal } \\
\text { behavior }\end{array}$} & $\begin{array}{l}\text { I utilize fashion products that are out of fashion or not } \\
\text { fitted by making alteration. }\end{array}$ & .890 & \multirow{2}{*}{1.777} & \multirow{2}{*}{63.140} & \multirow{2}{*}{.833} \\
\hline & $\begin{array}{l}\text { I reform fashion products that are out of fashion or not } \\
\text { fitted. }\end{array}$ & .881 & & & \\
\hline \multirow{2}{*}{$\begin{array}{c}\text { Social } \\
\text { disposal } \\
\text { behavior }\end{array}$} & $\begin{array}{l}\text { I put fashion products that I wouldn't wear any longer to } \\
\text { recycle bins nearby. }\end{array}$ & .768 & \multirow{2}{*}{1.020} & \multirow{2}{*}{73.339} & \multirow{2}{*}{.617} \\
\hline & $\begin{array}{l}\text { I hand down fashion products that I wouldn't wear any } \\
\text { longer to family, friends, cousins, or neighbors. }\end{array}$ & .638 & & & \\
\hline
\end{tabular}


$<$ Table 2> Factor analysis result of pursued value for fashion disposal

\begin{tabular}{|c|c|c|c|c|c|}
\hline Factors & Items & $\begin{array}{l}\text { Factor } \\
\text { loading }\end{array}$ & $\begin{array}{l}\text { Eigen } \\
\text { value }\end{array}$ & $\begin{array}{l}\text { Cumulative } \\
(\%)\end{array}$ & $\begin{array}{l}\text { Cronbach's } \\
\alpha\end{array}$ \\
\hline \multirow{4}{*}{$\begin{array}{c}\text { Environ- } \\
\text { mental- } \\
\text { social } \\
\text { value }\end{array}$} & $\begin{array}{l}\text { I donate fashion products that I wouldn't wear any longer } \\
\text { to charities or recycle bins in order to protect environment. }\end{array}$ & .797 & \multirow{4}{*}{2.385} & \multirow{4}{*}{21.680} & \multirow{4}{*}{.771} \\
\hline & $\begin{array}{l}\text { I donate fashion products that I wouldn't wear any longer } \\
\text { to charities or recycle bins in order to save resources. }\end{array}$ & .791 & & & \\
\hline & $\begin{array}{l}\text { I donate fashion products that I wouldn't wear any longer } \\
\text { to charities or second-hand stores to help others who are } \\
\text { in need instead of storing in my closet. }\end{array}$ & .768 & & & \\
\hline & $\begin{array}{l}\text { I like to give financial help to charities by donating } \\
\text { fashion products that I wouldn't wear any longer instead } \\
\text { of storing in my closet. }\end{array}$ & .673 & & & \\
\hline \multirow{2}{*}{$\begin{array}{l}\text { Practical } \\
\text { value }\end{array}$} & $\begin{array}{l}\text { I dispose fashion products that I wouldn't wear any longer } \\
\text { to make a room for new products. }\end{array}$ & .889 & \multirow{2}{*}{1.792} & \multirow{2}{*}{37.969} & \multirow{2}{*}{.785} \\
\hline & $\begin{array}{l}\text { I dispose fashion products that I wouldn't wear any longer } \\
\text { to have storage spaces. }\end{array}$ & .845 & & & \\
\hline \multirow{3}{*}{$\begin{array}{l}\text { Economical } \\
\text { value }\end{array}$} & $\begin{array}{l}\text { I want to receive financial rewards such as tax reduction } \\
\text { when I dispose fashion products that I wouldn't wear any } \\
\text { longer. }\end{array}$ & .752 & \multirow{3}{*}{1.735} & \multirow{3}{*}{53.739} & \multirow{3}{*}{.644} \\
\hline & $\begin{array}{l}\text { I think that exchanging un-needed fashion products with } \\
\text { other products is more economical than storing in my } \\
\text { closet. }\end{array}$ & .745 & & & \\
\hline & $\begin{array}{l}\text { I dispose fashion products that I wouldn't wear any longer } \\
\text { to make money by selling. }\end{array}$ & .592 & & & \\
\hline \multirow{2}{*}{$\begin{array}{l}\text { Hedonic } \\
\text { value }\end{array}$} & $\begin{array}{l}\text { I feel satisfaction of being neat and tidy when I dispose } \\
\text { fashion products that I wouldn't wear any longer. }\end{array}$ & .795 & \multirow{2}{*}{1.581} & \multirow{2}{*}{68.115} & \multirow{2}{*}{.652} \\
\hline & $\begin{array}{l}\text { I feel good when I dispose fashion products that I wouldn't } \\
\text { wear any longer. }\end{array}$ & .695 & & & \\
\hline
\end{tabular}

같이 고유치 1.0 이상인 4 요인이 추출되었고, 요인분 석 과정에서 요인부하량 .50 이하인 1 항목이 제거되 어 총 11 문항이 최종 분석에 사용되었으며, 요인의 총 변량은 $68.12 \%$ 였다. 요인 1 은 더 이상 입지 않는 패션 제품을 처분하고자 할 때, 환경보호나 자원절약 을 위해 자선단체나 중고상점 등에 기부하여 필요한 사람에게 도움을 주고자 하는 환경사회적 가치로 나 타났고, 요인 2 는 새로 산 패션 제품이나 물건을 보관 할 공간을 확보하기 위해 패션 제품을 처분하는 실용 적 가치, 요인 3 은 더 이상 입지 않는 패션 제품을 처 분하고자 할 때 세금혜택 등의 경제적 보상이나 물물 교환, 중고판매 등을 통해 경제적 이득을 취하고자
하는 경제적 가치, 요인 4는 더 이상 입지 않는 패션 제품을 처분함으로써 정리 정돈의 만족감이나 기분 이 좋아지는 쾌락적 가치로 명명하였다. 다항목 척도 간의 신뢰성을 크론바하 알파계수에 의해 분석한 결 과, 모든 요인의 신뢰 계수가 .60 이상을 보여 문항의 신뢰성이 검증되었다. 이러한 결과는 심층면접을 통 해 패션 제품을 처분할 때 추구하는 가치들을 밝혀낸 기존의 질적 연구(Albinsson \& Perera, 2009; HaBrookshire \& Hodges, 2009; Joung, 2014; Lee et al., 2013)의 결과를 적용하여 소비자의 처분 추구가치를 요인분석을 통해 실증적으로 검증하고, 유형을 분류 했다는 점에서 의미를 가진다. 


\section{3) Environmental awareness}

소비자의 환경의식 문항을 요인분석한 결과〈Table 3 과 같이 고유치 1.0 이상인 3 요인으로 추출되었으 며, 총 14 문항이 최종 분석에 사용되었고, 요인의 총 변량은 $68.75 \%$ 였다. 요인 1 은 패션 제품의 생산과정 에서 사용되는 유해 화학물질, 면 재배시 사용되는 농 약과 화학비료, 섬유나 의류 등의 폐기물로 인한 환 경훼손 등 패션산업이 환경에 미치는 나쁜 영향과 일 반적인 환경문제의 심각성에 대해 얼마나 알고 있는 가를 나타내는 패션관련 환경지식, 요인 2 는 개인의 노력과 행동이 환경문제 해결에 도움을 줄 수 있고, 사회에 변화를 일으킬 수 있으므로 의식적으로 행
동하고 소비하려는 소비자 효과성 지각, 요인 3은 평 소에 환경문제에 관심이 많고 분리수거를 열심히 실 천하고자 하며, 환경문제를 중요시 여기는 환경관심 으로 명명하였다. 다항목 척도 간의 신뢰성을 크론바 하 알파계수에 의해 분석한 결과, 모든 요인의 신뢰 계수가 .50 이상을 보여 문항의 신뢰성이 검증되었다.

\section{4) Sustainable fashion consumption attitude}

지속가능한 패션소비태도 문항을 요인분석한 결 과, 〈Table 4〉와 같이 고유치 1.0 이상인 3 요인이 추 출되었으며, 총 15 문항이 분석에 사용되었고, 이들의 설명력은 $68.99 \%$ 이다. 요인 1 은 중고패션 제품을 선

<Table 3> Factor analysis result of environmental awareness

\begin{tabular}{|c|c|c|c|c|c|}
\hline Factors & Items & $\begin{array}{l}\text { Factor } \\
\text { loading }\end{array}$ & $\begin{array}{l}\text { Eigen } \\
\text { value }\end{array}$ & $\begin{array}{c}\text { Cumulative } \\
(\%)\end{array}$ & $\begin{array}{c}\text { Cronbach's } \\
\quad \alpha\end{array}$ \\
\hline \multirow{5}{*}{$\begin{array}{c}\text { Fashion } \\
\text { related } \\
\text { environ- } \\
\text { mental } \\
\text { knowledge }\end{array}$} & $\begin{array}{l}\text { I am well aware that toxic chemicals are used in fashion } \\
\text { products. }\end{array}$ & .860 & \multirow{5}{*}{3.607} & \multirow{5}{*}{25.766} & \multirow{5}{*}{.886} \\
\hline & $\begin{array}{l}\text { I am aware that vast amount of insecticides and pesticides } \\
\text { are used in cotton crops. }\end{array}$ & .851 & & & \\
\hline & $\begin{array}{l}\text { I am aware that fabric scraps and used clothing would be } \\
\text { ended up in landfill and toxic substances are emitted during } \\
\text { incineration of synthetic fabrics. }\end{array}$ & .840 & & & \\
\hline & $\begin{array}{l}\text { I am aware of environmental impacts such as clothing waste, } \\
\text { air pollution, water contamination caused by fashion industry. }\end{array}$ & .817 & & & \\
\hline & $\begin{array}{l}\text { I am aware of environmental concerns such as global war- } \\
\text { ming. }\end{array}$ & .596 & & & \\
\hline \multirow{4}{*}{$\begin{array}{l}\text { Perceived } \\
\text { consumer } \\
\text { effective- } \\
\text { ness }\end{array}$} & $\begin{array}{l}\text { I think that personal effort can help solve environmental } \\
\text { problems. }\end{array}$ & .854 & \multirow{4}{*}{3.130} & \multirow{4}{*}{48.123} & \multirow{4}{*}{.869} \\
\hline & $\begin{array}{l}\text { I think that small acts of individual can ultimately help } \\
\text { society. }\end{array}$ & .834 & & & \\
\hline & I think that personal behavior can change society. & .833 & & & \\
\hline & $\begin{array}{l}\text { I try to act and consume with consideration under the impact } \\
\text { of personal behavior on environment and society. }\end{array}$ & .732 & & & \\
\hline \multirow{5}{*}{$\begin{array}{l}\text { Environ- } \\
\text { mental } \\
\text { concern }\end{array}$} & Environmental impact will be worsen if we do not recycling. & .828 & \multirow{5}{*}{2.888} & \multirow{5}{*}{68.753} & \multirow{5}{*}{.840} \\
\hline & $\begin{array}{l}\text { I am usually good at recycling such as plastic, glass, or } \\
\text { paper recycle. }\end{array}$ & .799 & & & \\
\hline & $\begin{array}{l}\text { I usually find recycling bins to separate garbages for re- } \\
\text { cycling. }\end{array}$ & .774 & & & \\
\hline & I am very concerned about environmental problems. & .578 & & & \\
\hline & Environmental problems are very important to me. & .529 & & & \\
\hline
\end{tabular}


$<$ Table 4> Factor analysis result of sustainable fashion consumption attitude

\begin{tabular}{|c|c|c|c|c|c|}
\hline Factors & Items & $\begin{array}{l}\text { Factor } \\
\text { loading }\end{array}$ & $\begin{array}{l}\text { Eigen } \\
\text { value }\end{array}$ & $\begin{array}{c}\text { Cumulative } \\
(\%)\end{array}$ & $\begin{array}{c}\text { Cronbach's } \\
\alpha\end{array}$ \\
\hline \multirow{5}{*}{$\begin{array}{l}\text { Used- } \\
\text { fashion } \\
\text { item } \\
\text { attitude }\end{array}$} & I like used-fashion items. & .888 & \multirow{5}{*}{3.588} & \multirow{5}{*}{23.918} & \multirow{5}{*}{.890} \\
\hline & I am interested in buying used-fashion items. & .865 & & & \\
\hline & I have a good feeling about used-fashion items. & .814 & & & \\
\hline & I purchased used-fashion items at second-hand stores. & .773 & & & \\
\hline & I think used-fashion items are practical. & .711 & & & \\
\hline \multirow{5}{*}{$\begin{array}{l}\text { Fashion } \\
\text { recycling } \\
\text { attitude }\end{array}$} & We need to recycle fashion items to save resources. & .841 & \multirow{5}{*}{3.510} & \multirow{5}{*}{47.321} & \multirow{5}{*}{.880} \\
\hline & It is desirable to recycle fashion items to save environments. & .819 & & & \\
\hline & We must recycle fashion items. & .804 & & & \\
\hline & It is desirable to recycle fashion items rather than throw-away. & .792 & & & \\
\hline & It is desirable to hand-down used-fashion items to others. & .742 & & & \\
\hline \multirow{5}{*}{$\begin{array}{l}\text { Fashion } \\
\text { innovative- } \\
\text { ness }\end{array}$} & I tend to buy trendy clothes before other people do. & .861 & \multirow{5}{*}{3.251} & \multirow{5}{*}{68.993} & \multirow{5}{*}{.863} \\
\hline & I am willing to pay more to buy latest fashion items. & .851 & & & \\
\hline & I do not want to wear out-of-fashion items. & .786 & & & \\
\hline & I like to buy latest fashion items and new products. & .765 & & & \\
\hline & I read fashion magazines to keep up with new trends. & .738 & & & \\
\hline
\end{tabular}

호하고, 구입에 관심이 많으며, 좋은 감정을 갖고 있 는 중고패션 제품태도, 요인 2는 자원낭비를 막고 환 경보호를 위해 패션 제품을 재활용해야 한다는 패션 재활용태도, 요인 3은 최신유행스타일에 대한 관심과 선호도를 나타내는 패션혁신성으로 명명하였다. 또한 다항목 척도 간의 신뢰성을 크론바하 알파계수에 의 해 분석한 결과, 모든 요인의 신뢰 계수가 .70 이상을 보여 신뢰성이 높다고 할 수 있다.

\section{The effect of pursuing value in disposal on} fashion disposal behavior

패션 제품 처분을 통해 추구하는 가치유형이 패션 처분행동에 미치는 영향을 알아본 결과, 〈Table 5〉와 같이 경제적 처분행동에는 경제적 가치 $(\beta=.469, t=$ $12.253)$, 실용적 가치 $(\beta=.264, t=6.891)$ 가 정적 영향 을 미쳤고, 쾌락적 가치 $(\beta=-198, t=-5.160)$ 는 부적 영향을 미쳤으며, 전체 설명력은 $33.2 \%$, 수정된 설명 력은 $32.6 \%$ 로 나타났다. 패션 제품을 처분할 때 중고 판매나 물물교환을 통한 경제적 이득, 세금 혜택 등
의 경제적 보상을 얻고자 하는 경제적 가치추구가 높 을수록, 새로운 패션 제품이나 물건을 보관할 공간을 확보하기 위한 실용적 가치추구가 높을수록 직접 중 고판매를 하거나, 중고 거래인을 통해 처분하는 경제 적 처분행동을 많이 한다고 볼 수 있다. 이와 같은 결 과는 폐기물을 줄이고자 하는 환경적 가치와 처분을 통해 돈을 절약하고자 하는 경제성이 중고패션 제품 의 재판매행동에 유의한 영향을 미친다고 밝힌 Joung and Park-Poaps(2013)의 연구결과와 부분적으로 일치 한다. 그러나 정리 정돈을 통한 만족감이나 긍정적인 기분을 갖고자 하는 쾌락적 가치추구가 높을수록 경 제적 처분행동은 덜 하는 것으로 나타났다.

실용적 처분행동에는 환경사회적 가치 $(\beta=.302, t=$ 6.804)만이 정적 영향을 미쳤고, 실용적 처분행동에 대한 처분 추구가치의 설명력은 $10.4 \%$, 수정된 설명력 은 $9.6 \%$ 의 결과를 보였다. 자원절약이나 환경보호, 필요한 사람에게 도움을 주고자 하는 환경사회적 가 치를 추구할수록 수선하거나 리폼하여 다시 활용하 는 실용적 처분행동을 많이 한다고 할 수 있다. 사회 
$<$ Table 5> The effect of pursued value on fashion disposal behavior

\begin{tabular}{|c|c|c|c|c|c|c|c|c|c|c|c|c|}
\hline \multirow{2}{*}{$\begin{array}{l}\begin{array}{c}\text { Dependent } \\
\text { Independent } \\
\text { variable }\end{array} \\
\text { variable }\end{array}$} & \multicolumn{3}{|c|}{ Economical disposal } & \multicolumn{3}{|c|}{ Practical disposal } & \multicolumn{3}{|c|}{ Social disposal } & \multicolumn{3}{|c|}{ Hoarding behavior } \\
\hline & $B$ & $\beta$ & $t$ & $B$ & $\beta$ & $t$ & $B$ & $\beta$ & $t$ & $B$ & $\beta$ & $t$ \\
\hline $\begin{array}{c}\text { Environmental- } \\
\text { social value }\end{array}$ & .054 & .054 & 1.408 & .302 & .302 & $6.804^{* * *}$ & .210 & .210 & $4.670^{* * *}$ & -.020 & -.020 & -.443 \\
\hline Practical value & .264 & .264 & $6.891^{* * *}$ & .068 & .068 & 1.536 & -.002 & -.002 & -.039 & .094 & .094 & $2.066^{*}$ \\
\hline Economical value & .469 & .469 & $12.253^{* * *}$ & .063 & .063 & 1.420 & -.040 & -.040 & -.881 & .222 & .222 & $4.892^{* * * *}$ \\
\hline Hedonic value & -.198 & -.198 & $-5.160^{* * *}$ & -.061 & -.061 & -1.377 & .178 & .178 & $3.946^{* * *}$ & -.038 & -.038 & -.847 \\
\hline$F$ & \multicolumn{3}{|c|}{$56.556^{* * *}$} & \multicolumn{3}{|c|}{$13.142^{* * *}$} & \multicolumn{3}{|c|}{$9.538^{* * *}$} & \multicolumn{3}{|c|}{$7.279^{* * *}$} \\
\hline$R^{2}$ & \multicolumn{3}{|c|}{.332} & \multicolumn{3}{|c|}{.104} & \multicolumn{3}{|c|}{.077} & \multicolumn{3}{|c|}{.060} \\
\hline Adj. $R^{2}$ & \multicolumn{3}{|c|}{.326} & \multicolumn{3}{|c|}{.096} & \multicolumn{3}{|c|}{.069} & \multicolumn{3}{|c|}{.052} \\
\hline
\end{tabular}

${ }^{*} p<.05,{ }^{* * *} p<.001$

적 처분행동에는 환경사회적 가치 $(\beta=.210, t=4.670)$ 와 쾌락적 가치 $(\beta=.178, t=3.946)$ 가 정적 영향을 미쳤 으며, 전체 설명력은 $7.7 \%$, 수정된 설명력은 $6.9 \%$ 였 다. 자원절약이나 환경보호, 필요한 사람에게 도움을 주고자 하는 환경사회적 가치를 추구할수록, 정리 정 돈의 만족감이나 패션 제품의 처분을 통해 좋은 기분 을 느끼고자 하는 쾌락적 가치를 추구할수록 주변사 람에게 증여하거나 자선단체나 자선상점에 기부하는 사회적 처분행동을 많이 한다고 볼 수 있다. 이는 환 경보호와 자선단체에 도움을 주고자 할수록 기부행 동을 많이 한다는 Joung and Park-Poaps(2013)의 연 구결과와도 일치하며, 소비자가 의류처분행동을 전후 로 타인을 돕는다는 기뽐, 정리정돈의 만족감 등의 긍정적인 감정을 느끼고, 패션 제품의 기부행동을 남 을 돕고자 하는 마음이나 자선에 대한 관심 등과 연 관시킨 여러 질적 연구의 결과(Birtwistle \& Moore, 2007; Ha-Brookshire \& Hodges, 2009; Lee et al., 2013) 를 양적 연구를 통해 처분 추구가치와 처분행동 간의 영향관계를 규명했다고 할 수 있다. 수동적 보관행동 에는 경제적 가치 $(\beta=.222, t=4.892)$ 와 실용적 가치 $(\beta=$ $.094, t=2.066)$ 가 정적 영향을 미쳤으며, 전체 설명력 은 $6.0 \%$, 수정된 설명력은 $5.2 \%$ 였다. 이는 소비자들 이 비싼 의류제품의 경우에는 입지 않더라도 보관하 는 경우가 많으며(Morgan \& Birtwistle, 2009), 국내 소비자의 경우 입지 않는 옷을 그대로 옷장에 보관하 는 경우가 많다는 선행연구(Han, 2009; Huh, 2007;
Kang, 2013)의 결과를 볼 때, 더 이상 입지 않는 패션 제품이라 할지라도 언젠가 처분할 때에는 경제적 보 상을 받거나, 수선이나 리폼을 통해 다시 입기를 바 라는 마음에서 옷장이나 신발장, 박스 등에 정리하여 보관을 하는 수동적 보관행동을 많이 한다고 추측할 수 있다. 하지만, 수동적 보관행동에 대한 처분 추구 가치의 설명력이 낮게 나타났으므로 본 연구의 결과 를 확대 해석하는데 신중을 기해야 할 것이다.

\section{The effect of environmental awareness on fa-} shion disposal behavior

소비자의 환경의식이 패션처분행동에 미치는 영향 을 알아본 결과, 〈Table 6〉과 같이 환경의식은 경제적 처분, 실용적 처분 및 사회적 처분행동의 적극적 처 분행동에 유의한 영향을 미쳤고, 소극적 처분인 수동 적 보관행동에는 영향을 미치지 않았다. 경제적 처분 행동에는 패션관련 환경지식 $(\beta=.230, t=5.106)$ 이 정 적 영향을, 환경관심 $(\beta=-.144, t=-3.190)$ 은 부적 영향 을 미쳤으며, 전체 설명력은 $7.7 \%$, 수정된 설명력은 $7.1 \%$ 였다. 즉, 패션산업과 관련한 환경지식의 수준이 높을수록 패션 제품을 처분할 때 경제적 이득을 취하 고자 하는 경제적 처분행동을 많이 한다고 볼 수 있 다. 그러나 환경관심이 높을수록 경제적 처분행동이 낮아지는 것으로 나타났으므로 환경에 대한 관심이 많고, 분리수거를 열심히 하며, 환경문제를 중요하게 생각하는 경우에는 패션 제품 처분에 있어 경제적 
$<$ Table 6> The effect of environmental awareness on fashion disposal behavior

\begin{tabular}{|c|c|c|c|c|c|c|c|c|c|c|c|c|}
\hline \multirow{2}{*}{$\begin{array}{l}\begin{array}{c}\text { Dependent } \\
\text { variable } \\
\text { variable }\end{array} \\
\text { variandent }\end{array}$} & \multicolumn{3}{|c|}{ Economical disposal } & \multicolumn{3}{|c|}{ Practical disposal } & \multicolumn{3}{|c|}{ Social disposal } & \multicolumn{3}{|c|}{ Hoarding behavior } \\
\hline & $B$ & $\beta$ & $t$ & $B$ & $\beta$ & $t$ & $B$ & $\beta$ & $t$ & $B$ & $\beta$ & $t$ \\
\hline $\begin{array}{c}\text { Fashion related } \\
\text { environmental } \\
\text { knowledge }\end{array}$ & .230 & .230 & $5.106^{* * *}$ & .200 & .200 & $4.366^{* * *}$ & .030 & .030 & .673 & .051 & .051 & 1.084 \\
\hline PCE & -.060 & -.060 & -1.331 & .055 & .055 & 1.201 & .126 & .126 & $2.791^{* *}$ & -.046 & -.046 & -.995 \\
\hline $\begin{array}{c}\text { Environmental } \\
\text { concern }\end{array}$ & -.144 & -.144 & $-3.190^{* *}$ & -.020 & -.020 & -.431 & .220 & .220 & $4.857^{* * *}$ & .067 & .067 & 1.434 \\
\hline$F$ & \multicolumn{3}{|c|}{$12.674^{* * *}$} & \multicolumn{3}{|c|}{$6.897^{* * *}$} & \multicolumn{3}{|c|}{$10.611^{* * *}$} & \multicolumn{3}{|c|}{1.408} \\
\hline$R^{2}$ & \multicolumn{3}{|c|}{.077} & \multicolumn{3}{|c|}{.043} & \multicolumn{3}{|c|}{.065} & \multicolumn{3}{|c|}{.009} \\
\hline Adj. $R^{2}$ & \multicolumn{3}{|c|}{.071} & \multicolumn{3}{|c|}{.037} & \multicolumn{3}{|c|}{.059} & \multicolumn{3}{|c|}{.003} \\
\hline
\end{tabular}

${ }^{* *} p<.01,{ }^{* * *} p<.001$

처분행동을 덜 한다고 볼 수 있다. 실용적 처분행동 에는 패션관련 환경지식( $\beta=.200, t=4.366)$ 만이 유의 한 영향을 미쳤으며, 실용적 처분행동에 대한 환경의 식의 설명력은 $4.3 \%$, 수정된 설명력은 $3.7 \%$ 의 결과 를 보였다. 이러한 결과는 의복관련 환경의식이 낮은 집단이 그렇지 않은 집단보다 수선 및 재활용 행동을 적게 한다는 $\mathrm{Han}(2009)$ 의 연구 결과를 뒷받침한다.

사회적 처분행동에는 환경관심 $(\beta=.220, t=4.857)$ 과 소비자 효과성 지각 $(\beta=.126, t=2.791)$ 이 유의한 영향을 미쳤고, 전체 설명력은 $6.5 \%$, 수정된 설명력은 $5.9 \%$ 였다. 특히 패션산업과 관련된 환경지식은 소비자의 패션 제품 처분행동 중 경제적 처분과 실용적 처분행 동에는 유의한 영향을 미쳤으나, 사회적 처분행동에 는 유의한 영향을 미치지 않았다. 이러한 결과는 패 션산업과 관련된 환경지식이 의복의 분리배출이나 기부 및 관리 등의 지속가능한 관리 처분행동에 유의 한 영향을 미치지 않으며(Suk \& Lee, 2013), 환경에 대한 지식은 자선단체에 기부하는 행동에 영향을 미 치지 않는다고 밝힌 연구(Bianchi \& Birtwistle, 2012) 의 결과와 맥락을 같이 한다. 반면, 평소에 분리수거 를 중요시하고, 환경에 대한 관심이 많은 소비자와 개인의 노력이 환경문제나 사회문제 해결에 도움을 줄 수 있다고 생각하는 소비자의 경우, 사회적 처분 행동을 많이 하고 있었는데, 이는 소비자의 재활용 행동과 환경에 대한 관심이 자선단체에 기부하는 기
부행동에 긍정적인 영향을 주며(Bianchi \& Birtwistle, 2012; Morgan \& Birtwistle, 2009), 소비자의 참여의 식과 환경보존 및 재활용에 관한 환경의식이 의복재 활용 행동에 정적인 영향을 준다는 선행연구(Park \& $\mathrm{Oh}, 2005)$ 의 결과를 뒷받침한다. 그러나 회귀분석 결 과의 설명력이 비교적 낮게 나타났으므로 결과의 확 대해석에 주의를 기해야 할 것이다.

\section{The effect of sustainable fashion consumption} attitude on fashion disposal behavior

소비자의 지속가능한 패션소비태도가 패션처분행 동에 미치는 영향을 알아본 결과, 〈Table 7〉과 같이 경제적 처분, 실용적 처분, 사회적 처분행동 및 수동 적 보관행동에 모두 유의한 영향을 미쳤다. 경제적 처 분행동에는 중고패션 제품태도 $(\beta=.336, t=7.888)$ 와 패 션혁신성 $(\beta=.239, t=5.629)$ 이 유의한 정적 영향을 미 쳤으며, 전체 설명력은 $17.5 \%$, 수정된 설명력은 $16.9 \%$ 로 나타났다. 즉, 중고패션 제품에 대한 선호도가 높 고, 중고제품 구매의사가 있으며, 유행에 관심이 많은 소비자는 패션 제품을 처분할 때 경제적 이득을 얻을 수 있는 중고판매나 중고거래인 이용, 물물교환 등을 더욱 많이 한다고 볼 수 있으며, 중고의류 구입에 호 의적인 태도를 가질수록 경제적 처분행동을 더 많이 한다는 선행연구의 결과(Jang \& Park, 1997)와 일치 한다. 
<Table 7> The effect of sustainable fashion consumption attitude on fashion disposal behavior

\begin{tabular}{|c|c|c|c|c|c|c|c|c|c|c|c|c|}
\hline \multirow{2}{*}{$\begin{array}{r}\begin{array}{r}\text { Dependent } \\
\text { variable }\end{array} \\
\text { Independent } \\
\text { variable }\end{array}$} & \multicolumn{3}{|c|}{ Economical disposal } & \multicolumn{3}{|c|}{ Practical disposal } & \multicolumn{3}{|c|}{ Social disposal } & \multicolumn{3}{|c|}{ Hoarding behavior } \\
\hline & $B$ & $\beta$ & $t$ & $B$ & $\beta$ & $t$ & $B$ & $\beta$ & $t$ & $B$ & $\beta$ & $t$ \\
\hline $\begin{array}{l}\text { Used-fashion item } \\
\text { attitude }\end{array}$ & .336 & .336 & $7.888^{* * *}$ & .247 & .247 & $5.452^{* * *}$ & -.044 & -.044 & -.971 & .143 & .143 & $3.113^{* *}$ \\
\hline $\begin{array}{c}\text { Fashion recycling } \\
\text { attitude }\end{array}$ & -.071 & -.071 & -1.660 & .056 & .056 & 1.227 & .203 & .203 & $4.446^{* * *}$ & .075 & .075 & 1.621 \\
\hline $\begin{array}{c}\text { Fashion } \\
\text { innovativeness }\end{array}$ & .239 & .239 & $5.629^{* * *}$ & -.012 & -.012 & -.266 & .086 & .086 & 1.878 & .099 & .099 & $2.152^{*}$ \\
\hline$F$ & \multicolumn{3}{|c|}{$32.221^{* * *}$} & \multicolumn{3}{|c|}{$10.433^{* * *}$} & \multicolumn{3}{|c|}{$8.078^{* * *}$} & \multicolumn{3}{|c|}{$5.620^{* *}$} \\
\hline$R^{2}$ & \multicolumn{3}{|c|}{.175} & \multicolumn{3}{|c|}{.064} & \multicolumn{3}{|c|}{.050} & \multicolumn{3}{|c|}{.036} \\
\hline Adj. $R^{2}$ & \multicolumn{3}{|c|}{.169} & \multicolumn{3}{|c|}{.058} & \multicolumn{3}{|c|}{.044} & \multicolumn{3}{|c|}{.029} \\
\hline
\end{tabular}

${ }^{*} p<.05,{ }^{* *} p<.01,{ }^{* * *} p<.001$

실용적 처분행동에는 중고패션 제품태도 $(\beta=.247$, $t=5.452)$ 만이 유의한 정적 영향을 미쳤으며, 실용적 처분행동에 대한 지속가능한 패션소비태도의 설명력 은 $6.4 \%$, 수정된 설명력은 $5.8 \%$ 의 결과를 보였다. 이 는 슬로패션 구매의사가 있는 집단이 교환 및 판매, 수선 등 친환경적 처분행동을 많이 한다는 $\operatorname{Han}(2009)$ 의 연구결과와 일치하며, 중고의류구입태도가 경제적 처분과 다른 용도로 개조하는 실용적 처분행동에 유 의한 정적 영향을 미친다고 밝힌 Jang and Park(1997) 의 연구결과를 뒷받침한다. 사회적 처분행동에는 패 션재활용태도( $\beta=.203, t=4.446)$ 만이 유의한 정적 영향 을 미쳤으며, 사회적 처분행동에 대한 지속가능한 패 션소비태도의 설명력은 $5.0 \%$, 수정된 설명력은 $4.4 \%$ 였다. 이는 의류재활용에 대한 태도가 이타적 처분에 유의한 영향을 미치고(Jang \& Park, 1997), 소비자의 재활용 행동이 기부행동에 영향을 미친다(Bianchi \& Birtwistle, 2012)는 기존 연구의 결과와 일치하며, 슬 로우 패션구매의사가 있는 집단의 경우, 의복 처분에 있어 수선, 활용이나 교환 및 재판매행동을 하는 것 으로 나타난 $\operatorname{Han}(2009)$ 의 결과와 맥락을 같이 한다. 마지막으로, 수동적 보관행동에는 중고패션 제품태 도 $(\beta=.143, t=3.113)$ 와 패션혁신성 $(\beta=.099, t=2.152)$ 이 유의한 정적 영향을 미쳤으나, 전체 설명력이 $3.6 \%$, 수정된 설명력이 $2.9 \%$ 로서 결과의 확대 해석에 주의 를 요한다. 이 결과는 패스트 패션 구매자들이 폐기와
수동적 보관을 많이 하고, 재활용 행동을 적게 한다는 Joung(2014)의 질적 연구와 미래에 다시 필요하게 될 지도 모른다는 불안감에서 수동적 보관을 한다는 Lee et al.(2013)의 질적 연구의 결과를 뒷받침한다.

\section{Conclusion}

본 연구는 소비행동의 마지막 단계이자 구매나 사 용 못지않게 중요한 소비자의 패션처분행동을 이해 하기 위하여 처분행동의 유형을 알아보고 처분 추구 가치, 환경의식, 지속가능한 패션소비태도가 패션처 분행동에 미치는 영향을 분석하여 자원의 선순환과 환 경보존, 사회적 책임을 다하는 지속가능한 패션소비 행동을 유도할 수 있는 방안을 제공하고자 하였다. 이를 위해 국내 소비자를 대상으로 실증분석을 실시 한 결과, 첫째 소비자의 패션처분행동은 경제적, 실용 적, 사회적 처분행동과 수동적 보관행동으로 분류되 었다. 패션 제품 처분 시 추구하는 가치는 환경사회 적, 실용적, 경제적, 쾌락적 가치 추구로 구분되었으 며, 환경의식은 패션관련 환경지식, 소비자효과성지 각, 환경관심으로 구성되었고, 지속가능한 패션소비 태도는 중고패션 제품, 패션재활용, 패션혁신성으로 분류되었다. 둘째, 패션 제품 처분 시 경제적 가치와 실용적 가치 추구는 경제적 처분과 수동적 보관행동 에 긍정적인 영향 요인이었고, 환경사회적 가치는 실 
용적, 사회적 처분행동에 긍정적인 영향을 미치고 있 었다. 쾌락적 가치는 경제적 처분행동에는 부정적 영 향을 보였으나, 사회적 처분행동에는 긍정적 영향을 미쳤다. 셋째, 패션관련 환경지식은 경제적 처분과 실 용적 처분행동에, 소비자효과성지각은 사회적 처분행 동에 긍정적인 영향을 미쳤고, 환경관심은 경제적 처 분행동에는 부정적인 영향을 미치고 있었지만, 사회 적 처분행동에는 긍정적인 영향을 미쳤다. 넷째, 중고 패션 제품에 대한 태도는 경제적 처분, 실용적 처분, 수동적 보관행동에 모두 긍정적인 영향을 미쳤으며, 패션혁신성은 경제적 처분과 수동적 보관행동에, 패 션재활용태도는 사회적 처분행동에 긍정적인 영향을 미쳤다.

본 연구의 결과를 고려하여 시사점을 제안하면 다 음과 같다.

첫째, 소비자들이 자원절약이나 환경보호, 타인에게 도움을 주고자 하는 환경사회적 가치를 추구할수록, 중고패션 제품을 선호하고 관심이 많을수록, 패션관 련 환경지식이 높을수록 리폼이나 수선을 통해 재활 용하는 실용적 처분행동을 많이 하는 것으로 나타났 다. 실용적 처분행동은 자원의 선순환과 제품의 라이 프사이클을 연장시킨다는 점에서 지속가능한 소비의 일환이라고 볼 수 있으므로, 소비자를 대상으로 패션 제품의 리폼이나 수선에 관한 다양한 아이디어와 정 보를 제공하고, 패션 재봉 전문인들과 파트너십으로 단순한 리폼이나 수선에서부터 자원의 업 사이클링 에 이르기까지 소비자가 직접 참여하고 활용할 수 있 는 공방이나 워크샵, 패션 업사이클링 수업 등을 개 설한다면 실용적 처분행동을 늘릴 수 있을 것이다.

둘째, 소극적 처분행동인 수동적 보관은 기존의 많 은 연구에서 처분행동의 범위에서 제외되어 왔다. 그 러나 본 연구의 결과, 더 이상 입지 않는 패션 제품을 처분할 때 실용적 가치와 경제적 가치를 추구할수록, 중고패션 제품에 관한 관심과 선호도, 패션혁신성이 높을수록 수동적 보관행동을 많이 하는 것으로 나타 났다. 즉, 소비자들은 지금 당장 입거나 사용하지 않 지만 언젠가 필요하게 되거나, '유행은 돌고 돈다'는 말처럼 미래에 다시 입게 될지도 모른다는 막연한 기 대감, 그리고 당장 처분하지 않더라도 처분하게 된다 면 판매나 교환 등을 통한 경제적 가치를 얻고자 하 는 욕구가 적극적인 처분보다는 소극적 처분행동을
유도한다고 볼 수 있다.

많은 소비자들은 넘쳐나는 옷장을 보며 죄책감이 나 부담감 등의 부정적인 감정을 느끼기도 하고, 고 가의 제품일수록 그대로 보관하는 경향이 있으며 최 근 소비자의 패션 제품 구매량이 늘면서 이러한 현상 이 심해지고 있다. 현재 중고패션 제품의 교환이나 판매는 인터넷 중고거래 사이트나 어플리케이션, 중 고매장을 통한 개인 간의 거래 또는 무게 당 비용을 지불하고, 헌옷을 수거해가는 중고 거래인의 이용이 일반적이다. 중고 거래인이 수거한 제품의 경우, 대부 분이 제 3 국으로 수출되고, 수많은 자선단체가 헌 옷 을 기부해 왔으나 이러한 방식이 결국 제 3 국의 의류 산업 발전을 저해하고, 그 지역의 환경적 부담을 증 가시킨다는 이유로 동아프리카공동체(East African Community)에서 헌 옷의 수입을 금지시키는 법안을 발의하면서, 과연 제 3 국으로의 수출이 지속가능성의 관점에서 볼 때 옳은 일인가에 관해 생각해 볼 필요 가 있다. 따라서 소비자의 경제적 가치추구의 욕구를 충족시키면서 동시에 중고패션 제품의 활용을 좀 더 활성화 시키려면 중고패션시장의 형태와 운영방식이 좀 더 다양화, 전문화 되어야 한다. 패션혁신성이 높 은 소비자일수록 수동적 보관행동을 많이 한다는 연 구의 결과를 볼 때, 이들을 타깃으로 한 중고패션시 장의 가능성을 확인해 볼 수 있다. 이를 위해서는 현 재 중고매장으로 운영되고 있는 아름다운 가게, 굿윌, 구세군 등의 매장과 차별화되어야 하며, 국내 빈티지 매장의 경우, 일본이나 미국, 유럽 등지에서 수입되는 제품이 대부분이지만, 국내에서 수거되는 중고제품의 재사용을 적극 활용하기 위한 공급과 판매 인프라가 구축되어야 할 것이다.

셋째, 소비자들의 쾌락적 가치는 경제적 처분행동 에 부적 영향을 미치고, 사회적 처분행동에는 긍정적 인 영향을 미치는 것으로 나타났는데, 이는 처분을 통해 경제적 보상이나 이득을 추구하기 보다는 기부 나 증여 등의 사회적 처분행동을 통해 타인을 돕는다 는 기쁨, 즉 이타적 쾌락을 추구한다고 볼 수 있다. 또한 평소 환경에 관한 관심이 많고, 분리수거를 잘 하고, 환경문제를 중요시 할수록 패션 제품을 처분할 때 경제적 이득을 취하는 행동은 덜하고, 기부나 증 여를 통한 사회적 처분행동을 많이 함을 알 수 있다. 최근 문제가 불거진 헌 옷 수거함의 경우, 설치 주체 
와 목적이 불분명하여 소비자에게 의구심을 불러일으 키고 있는 만큼, 소비자들이 사회적 처분행동을 통해 이타적 쾌락과 환경문제 해결에 도움을 줄 수 있다는 점을 확신할 수 있도록 헌 옷 수거함에 설치 주체와 목적을 명시하고, 기부된 제품들의 유통정보를 공개 하여야 할 것이다.

마지막으로, 대량생산과 대량소비의 시대에서 패 션 폐기물은 환경오염의 주범으로 비난의 대상이 되 고 있고, 패션기업은 생산과정에서의 폐기물이나 재 고의류의 선순환에 대해 관심을 갖고 새로운 시도를 시작하고 있지만, 정작 옷장에 넘쳐나는 옷을 어떻게 처분해야 할 것인가를 고민하는 소비자의 패션처분 행동에 대한 연구는 부족했다. 본 연구는 소비자의 패션처분행동의 유형을 분류하고, 처분 추구가치나 중고패션 제품, 패션재활용, 패션혁신성 등 여러 질적 연구를 통해 알려진 변인들과 처분행동 간의 영향관 계를 양적 연구를 통해 규명함으로써 연구의 영역을 확장하였으며, 본 연구에서 사용한 패션처분행동과 추구가치 및 지속가능한 패션소비태도의 측정도구를 후속 연구에서도 적용할 수 있을 것이다.

본 연구에서는 패션처분행동의 영향요인으로 처분 추구가치, 환경의식, 지속가능한 패션소비태도를 다 루었으나, 소비자들이 고가의 의류제품을 처분할 때 는 죄책감을 더 느끼고, 자선단체에 기부하는 경우가 많지만, 가격이 저렴한 패스트 패션 아이템의 경우, 단순폐기하는 경우가 많다(Morgan and Birtwistle, 2009)는 점을 고려하면 처분할 제품의 가격에 대해서 도 다룰 필요가 있으며, 제품의 디자인, 품질 등 물리 적 속성이나 제품과 연관된 추억, 감정적 유대감 등 의 심리적 속성, 긍정적이거나 부정적인 감정 등도 처분행동에 영향을 줄 수 있으므로 이에 대한 후속 연구가 요구된다. 또한 처분 추구가치, 환경의식, 지 속가능한 패션소비태도와 패션처분행동 간의 회귀분 석 결과에서 설명력이 비교적 낮게 나타난 한계가 있 으므로, 질적 연구를 통해 요인의 수를 확대한 후, 양 적 연구를 실시한다면 설명력을 높일 수 있을 것이 다. 이 외에 패션처분행동에 대한 국내외 소비자의 비교연구를 실시하거나, 패스트 패션 제품과 럭셔리 패션 제품의 비교 연구가 이루어진다면, 소비자의 처 분행동을 이해하고 좀 더 지속가능한 소비행동을 이 끌어 내는 도움이 될 것이다.

\section{References}

Ahn, S.-K., \& Ryou, E. (2015). The effects of clothing consumption value and demographic features on clothing disposal behaviors. Fashion \& Textile Research Journal, 17(6), 956-964. doi:10.5805/SFTI. 2015.17.6.956

Albinsson, P. A., \& Perera, B. Y. (2009). From trash to treasure and beyond: The meaning of voluntary disposition. Journal of Consumer Behaviour, 8(6), 340-353. doi:10.1002/cb.301

Bianchi, C., \& Birtwistle, G. (2010). Sell, give away, or donate: An exploratory study of fashion clothing disposal behaviour in two countries. The International Review of Retail, Distribution and Consumer Research, 20(3), 353-368. doi:10.1080/ 09593969.2010 .491213

Bianchi, C., \& Birtwistle, G. (2012). Consumer clothing disposal behavior: A comparative study. International Journal of Consumer Studies, 36(3), 335-341. doi:10.1111/j.1470-6431.2011.01011.x

Birtwistle, G., \& Moore, C. M. (2007). Fashion clothing - where does it all end up?. International Journal of Retail \& Distribution Management, 35(3), 210-216. doi:10.1108/09590550710735068

Cho, H.-J. (2010). Aspect and meaning of social discussion in media discourse of clothing reuses. 실 천민속학연구 [Journal of Practice Folkloristics], 16, 121-165.

Choi, E. J., \& Kim, Y.-S. (2007). An effect of values, environmental knowledge, and environmental involvement on the ecologically concerned behavior of college students. Journal of Consumption Culture, 10(3), 15-41.

Choo, T. G., \& Park, H. H. (2013). The effect of consumption value on attitude and repurchase intention of secondhand fashion goods: The moderating role of self-confidence in fashion coordination. Journal of the Korean Society of Clothing and Textiles, 37(4), 618-630. doi:10.5850/JKSCT. 2013.37.4.618 
Ha-Brookshire, J. E., \& Hodges, N. N. (2009). Socially responsible consumer behavior?: Exploring used clothing donation behavior. Clothing \& Textiles Research Journal, 27(3), 179-196. doi:10.1177/ 0887302X08327199

Han, S.-H. (2009). A study on the purchasing behavior and usage of environmentally friendly clothing and the disposal of clothing. Journal of Korean Home Management Association, 27(3), 61-77.

Harrell, G. D., \& McConocha, D. M. (1992). Personal factors related to consumer product disposal tendencies. The Journal of Consumer Affairs, 26(2), 397-417. doi:10.1111/j.1745-6606.1992.tb00034.x

Huh, K.-G. (2007). Consumer's pro-environmental behavior relating to clothing by the style of purchase behavior. Journal of Korean Home Management Association, 25(2), 23-36.

Hvass, K. K. (2014). Post-retail responsibility of garments: A fashion industry perspective. Journal of Fashion Marketing and Management: An International Journal, 18(4), 413-430. doi:10.1108/JFMM01-2013-0005

Jang, G. H., \& Park, J. O. (1997). The effects of the socially responsible clothing consumption attitude on the clothing disposition behavior(Part I). Journal of the Korean Society of Clothing and Textiles, 21(4), 795-805.

Joung, H.-M. (2014). Fast fashion consumers' postpurchase behaviour. International Journal of Retail \& Distribution Management, 42(8), 688-697. doi: 10.1108/IJRDM-03-2013-0055

Joung, H.-M., \& Park-Poaps, H. (2013). Factors motivating and influencing clothing disposal behaviours. International Journal of Consumer Studies, 37(1), 105-111. doi:10.1111/j.1470-6431.2011.01048.x

Kang, Y. S. (2013). Research on the recycling and disposal of unused clothes by women. Korean Society of Fashion Design, 13(4), 61-84.

Kim, S. W., \& Cho, H. S. (2000). A study on clothing recycling disposition behavior: Focusing on the unmarried women workers. Journal of Korean
Home Management Association, 18(2), 15-27.

Kwon, K. D., Kim, S. H., \& Lee, S. J. (2002). An exploratory study on relations between fashion life style \& consumer behavior at decline stage of the fashion life cycle. Journal of the Korean Society of Clothing and Textiles, 26(2), 280-291.

Lang, C., Armstrong, C. M., \& Brannon, L. A. (2013). Drivers of clothing disposal in the US: An exploration of the role of personal attributes and behaviours in frequent disposal. International Journal of Consumer Studies, 37(6), 706-714. doi:10.1111/ijcs. 12060

Lee, J. Y., Halter, H., Johnson, K. K. P., \& Ju, H. (2013). Investigating fashion disposition with young consumers. Young Consumers, 14(1), 67-78. doi:10.1108/17473611311305494

Morgan, L. R., \& Birtwistle, G. (2009). An investigation of young fashion consumers' disposal habits. International Journal of Consumer Studies, 33(2), 190-198. doi:10.1111/j.1470-6431.2009.00756.x

Park, H. H., \& Oh, S. D. (2005). The influence of materialism and environment consciousness on recycling attitude and behavior of clothing. Family and Environment Research, 43(10), 167-177.

Park, J.-M., \& Shin, H. W. (2014). Environmental consciousness, clothing recycling behavior and interest in fashion by awareness of upcycling and purchasing behavior for upcycled fashion products of middle \& high school students. Journal of Korean Home Economics Education Association, 26(2), 89-99.

Park, S.-A., Park, J.-O., \& Lee, J.-Y. (2014). The influence of environmental consciousness and socially responsible clothing consumption attitude on perceived consequences of fast fashion. The Research Journal of the Costume Culture, 22(2), 225-239. doi:10.7741/rjcc.2014.22.2.225

Roh, Y.-L., \& Kim, S.-W. (2002). A study on environmental and recycling consciousness and behavior of consumers' recycling: Focused on the unused clothing of unmarried working women. Family 
and Environment Research, 40(1), 163-178.

Suk, H. (2015). Consumer's perception of fashion companies' sustainability and its effect on trust, preference, and purchase intention. Journal of the Korean Society of Clothing and Textiles, 39(5), 656-671. doi:10.5850/JKSCT.2015.39.5.656

Suk, H., \& Lee, E.-J. (2013). The value, knowledge, and sustainable consumption behavior of fashion consumers. Journal of the Korean Society of Clothing and Textiles, 37(3), 424-438. doi:10.5850/
JKSCT.2013.37.3.424

The environmental costs of creating clothes. (2017, April, 11). The economist, Retrieved April 14, 2017, from http://www.economist.com/blogs/economistexplains/2017/04/economist-explains-6

Yoon, S. I., Jin, K.-N., \& Kang, H. S. (2013). A study on characteristics and consumption revitalization strategies of sustainable fashion industry: Focused reused and recycled fashion industry. Journal of Korea Design Forum, 40, 305-314. 